\title{
Articles
}

\section{The Influence of Content Knowledge on NNS-NNS Conversations}

\section{Yuh-Fang Chang \\ National Chung Hsing University}

In the field of second and foreign language acquisition, a second-language learner's language (i.e. interlanguage), like the language of native speakers, varies. What is not clear, however, are the underlying causes of this variation. Causes of interlanguage variation such as linguistic contexts, tasks, and interlocutors have been researched. However, there are other important factors in interlanguage variation that are under-researched. Topic of discourse is one such under-researched factor. The purpose of this study was to examine the relationship between discourse topics and second language learners' oral performance. Twenty-six Taiwanese students participated in this study. Data were collected from NNS-NNS conversations. It was found that discourse topics have a great impact on the grammatical complexity and fluency of L2 learners' speech production.

第二言語習得および外国語の習得の研究において、学習者の言語(いわゆる中間言語)に母 語話者の習得言語と同様に変異が認められるということはよく知られている。しかしだ解明され ていないのは何が変異を起こしているのかというその要因である。言語、文脈、タスク、対話者 などの要因についてはこれまで比較的多く研究されている。しかしながら談話上のトピックにつ いてはほとんど調査が行わ饥ていない。本研究の目的は談話上のトピックと学習者の発話行動 の関係を探ることである。本調査には26名の台湾人の学生が参加した。非母語話者どうしの対 話からデー夕を収集し分析した結果、談話のトピックは文法構造の複雑度および流暢さに大きく 影響することがわかった。

JALT Journal, Vol. 30, No. 2, November, 2008 
T $\mathrm{n}$ the field of second and foreign language acquisition, it is now widely recognized that a second-language learner's language (i.e. interlanguage), like the language of native speakers, varies. Several causes of interlanguage variation such as linguistic contexts, tasks, and interlocutors have been identified and researched. However, there are other factors in interlanguage variation that remain unexplored or underresearched. Topic of discourse is one such factor. As Tarone (1988) states, "the topic of communication... is one of the most under-researched areas in the study of interlanguage variation" and "the precise effects of topic upon variation have yet to be established" (p. 119). In the same vein, and more recently, Ellis (2003) pointed out that topic effect has received little attention from researchers. While in the past 15 years, the effect of discourse topic on L2 oral performance has increasingly received a great deal of scrutiny, the research designs and contexts have varied, and the findings have been inconclusive. In order to arrive at a better understanding of topic-related interlanguage variation, the present study aimed to: (1) describe the relationships between discourse topics and second-language learners' participation in NNS-NNS conversations; and (2) describe the relationships between discourse topics and the fluency and grammatical development of these learners' oral production.

\section{Literature Review}

To investigate the relationship between topic familiarity and L2 learners' oral performance, Selinker and Douglas (1985, 1986, 1987, 1989) conducted a series of case studies involving interviews of non-native graduate students on work and life domain topics. Selinker and Douglas (1985) collected data from two informant sessions. One was an interview conducted by one of the researchers with a technical text as the focus. The second informant session was an interview conducted by the research assistant, who was a friend of the subject. It was found that the subjects employed different communicative strategies and rhetorical organization in talking about their major fields from those they used in talking about their own lives or culture. For instance, one subject appeared to be competent and confident in talking about his major field, able to circumvent vocabulary gaps and to correct his native interlocutor, but seemed less motivated to find vocabulary items and more deferential in life-domain talk.

In their subsequent studies, Selinker and Douglas (1986) employed a research design similar to that of the previous study except that the data 
on subjects' oral production were elicited from various contexts: a class presentation on a mathematics problem, Chinese music, a group conversation, and an interview. It was found that the rhetorical organization differed across topics. The Selinker and Douglas studies have certainly provided insight into topic-related interlanguage variation. However, the results of their studies must be interpreted cautiously because of the data collection process employed. In their studies, they either used different interviewers to interview the subject (1985), or they elicited the oral production from various contexts (1986).

In Selinker and Douglas (1985), the data were collected in two interviews: one by a professor interviewing the subject on the topic of his major field and the other by a research assistant, who was a friend of the subject, on the topic of the student's everyday life. Hence, the different communicative strategies that researchers found from the subjects' talk in the two domains may result from interlocutor factors. In Selinker and Douglas (1986), the data were collected from both class presentations and group conversations. The differences that researchers observed in the subjects' rhetorical organization across discourse domains may have been caused by the difference between planned and unplanned discourse.

Selinker and Douglas (1985) proposed a discourse domain hypothesis which is based on the notion of specialized contexts for language development emerging from these research findings. Selinker and Douglas (1986) defined the discourse domains as a "personally and internally constructed 'slice' of one's life that has importance and over which the learner exercises content-control" (p. 4). Examples of "slices of life" include job, research and personal life. The discourse domain hypothesis generated the following predictions:

1. In creating interlanguages (ILs), a learner creates discourse domains and uses them to develop his/her IL structure(s)... The important processes in IL learning (e.g., fossilization, backsliding, language transfer, communicative strategies) rarely occur across ILs, but occur primarily within discourse domains.

2. Discourse domains influence the syntactic units of IL learning.

3. No IL learner is monostylistic.

This hypothesis, although intuitively appealing, has not attracted much attention from researchers. In addition to the studies done by Selinker and Douglas (1985, 1986, 1987, 1989), only five reported studies 
(Cornu \& Delahaye, 1987; Whyte, 1992, 1993, 1994a, 1994b, 1995) have investigated the discourse domain hypothesis. Among these studies, the research findings are not consistent.

Cornu and Delahaye (1987) collected two sets of data from the DutchFrench interlanguage of two university economics students to investigate the discourse domain hypothesis. The data consisted of a conversation on subjects' hobbies, then a five-minute break, followed by a second conversation on the target topic area. The analysis of data revealed significant differences in the syntactic, rhetorical, strategic and lexical areas between the subjects' conversations on the two topics. The number of embedded sentences was far greater in the conversation for the subject's major field (referred to as C2 hereinafter) than for the subject's hobbies (C1). The errors were corrected much more readily in $\mathrm{C} 2$ than in $\mathrm{C} 1$. In addition, verbs were used more appropriately in C2 than in C1.

Whyte (1992, 1993, 1994a, 1994b, 1995) designed a series of studies to test the discourse domain hypothesis. The first (1992) was a case study of a French mathematics graduate student who was interviewed by two nonspecialist native speakers. The data were analyzed in terms of discourse organization. It was shown that the subject performed differently in discourse organization related to the domain of talk. Talk on certain math domain topics was characterized by lengthy time at talk, including long, structured turns, illustrating the speaker's content control of the topic.

Whyte (1993) examined talk by four international professionals on topics in their work and life domains, as well as on general topics. In addition to discourse analysis, data were analyzed for fluency (i.e., speech time, turn length, and hesitation) and grammatical accuracy (i.e., past tense, copula, and noun marking in obligatory contexts). Results were mixed, although one subject emerged clearly as more fluent and accurate in conversation on topics in his professional field than on talk in his life domain.

In the third study, Whyte (1994a) collected data from the performance of eight advanced ESL students discussing their academic major topics which were compared with data on a general topic. As in the second study, the results were mixed. Only one subject performed more accurately and fluently on the topic with which he was familiar. Whyte (1994b, 1995) employed a research design similar to that of the previous study (Whyte 1994a) and distributed a post-interview questionnaire to subjects to verify their views on the topics discussed. The analysis of grammatical complexity and accuracy showed no cross-topic variation for either the invested or control subjects. The analysis of discourse organization 
revealed evidence in support of the predictions that domain talk would be constructed more independently and more coherently than general talk. All invested subjects constructed longer episodes in talk on their academic major topics.

Even though limited research has been done to investigate the discourse domain hypothesis, several studies have been conducted to examine how topic influences a second language learner's participation in conversations. Eisenstein and Starbuck (1989) showed that learners' expertise in the discourse topic has a great impact on L2 learners' pronunciation. Zuengler (1989, 1993a, 1993b), and Zuengler and Bent (1991) investigated the relationship between topic knowledge and participation in conversations in NS-NNS interactions. In dyads consisting of subjects with different expertise levels, the results showed that interlocutors with greater content expertise (true both for NS and NNS relative content experts) participated more actively in the conversation than did their "non-expert" partners. The relative experts produced significantly more talk and more fillers. Zuengler's work on conversational interaction has shown that topic expertise may have a positive effect on learner production.

In the same vein, studies by Woken and Swales (1989) revealed that in NS-NNS interaction, greater content knowledge resulted in non-native speakers' dominance in dyadic conversations. Woken and Swales (1989) conducted a study to investigate how topic knowledge affects the NSNNS interaction pattern. Six female subjects participated in the study. The NNSs, who were familiar with Volkswriter (a 1980's-era word processor), were asked to introduce it to NSs. They were paired into three dyads, each consisting of one native and one non-native speaker of English. It was found that the non-natives dominated in the conversation and generally exceeded the natives in the length of T-unit. In addition, the NSs did most of the inquiring. The non-natives supplied the natives with vocabulary, teaching them key terms from the subject area.

It is clear that research on topic-related interlanguage variation is in its infancy. The literature concerning the topic effects on learners' interlanguage variation is scant and the research findings are not consistent. Furthermore, the precise effects of the discourse topic on IL variation have not yet been established. For example, whereas Chang (2002) and Whyte $(1992,1994 a, 1995)$ found topic effects for expert speakers in terms of fluency and discourse features, Whyte (1994b) did not find cross-topic differences in fluency measures. While several studies have shown that the discourse topic affects the syntactic area of learners' oral production (e.g., Cornu \& Delahaye, 1987; Woken \& Swales, 1989; Young, 1991), stud- 
ies by Douglas and Selinker (1992, 1993,1994), Smith $(1989,1992)$, Whyte (1994b) and Chang (2002) did not find any topic effect on the syntactic area of learners' oral production.

Aside from the dearth of research on topic-related interlanguage variation and the inconclusive findings, previous studies have also suggested that special care in the research design of further study is needed. Most studies collected NS-NNS interaction data through interviews and some studies even compared the data elicited by different interviewers on different topics. This introduces an interlocutor factor into the studies as a confounding variable. Moreover, the majority of studies contrasted participants' performance on an academic major topic and a life story topic. Researchers assigned the topics assuming that the academic major topic was the discourse topic with which L2 learners were familiar and on which they would perform better. Individual differences, however, may need to be taken into consideration. Although assuming that international students can perform better on a topic from their major field than on other so-called "general" topics seems reasonable, the assumption fails to consider that for some learners, the input (content knowledge) that they get does not necessarily become output because of the linguistic barrier. It is more likely that it is the participant who knows the topic with which he/ she is most familiar, and this need not be the topic of specialization.

If the purpose of the study is to examine the topic effects on learners' interlanguage variation, a research design which avoids the interlocutor factor as a possible confounding variable and takes individual differences into consideration is necessary. The present study attempted to contribute to this developing research with an investigation using a research design avoiding the aforementioned problems. The units of analysis chosen for the present study were based on the following review of the research.

\section{Unit of analysis}

This study examined participants' performance from the perspectives of fluency and syntactic development. Since the discourse domain hypothesis predicts that learners will perform better on the domain topics, more fluent and more target-like syntactic structures were expected in participants' utterances on the familiar topics than on the unfamiliar topics. Fluency is defined by Schmidt (1992) as automatic procedural skill. He points out that the ability to produce fluent speech is a skill "emphasizing the performance aspect of actually doing something in real time rather than the knowledge of how something is to be done" (p. 395). In the same 
vein, Skehan (1996a) defined fluency as the capacity of the learner to mobilize his/her system to communicate meaning in real time. Studies by Lennon (1990) and Riggenbach (1991) in which native-speaker ratings of fluency in non-native speech were compared with microanalyses of samples of that speech have shown that speech rate and number of pauses correlated with the listener's perception of fluency. Due to the technical nature of research into pausing in speech production, the present study has confined itself to an analysis of speech rate, an approach commonly used by L2 researchers to measure fluency (e.g., Whyte, 1994; Ellis, 2005). Following Riggenbach (1991), a measure of words per minute was used. In addition, this study included a global measure of the amount of talk which has also been used in second language research to gauge learner fluency (Woken \& Swales, 1989; Zuengler, 1989; Zuengler \& Bent, 1991).

Each participant's syntactic development was measured in terms of the grammatical complexity and grammatical accuracy of utterance. According to Skehan (1996b), accuracy refers to "how well the target language is produced in relation to the rule system of the target language" (p. 23). Complexity is concerned with the extent to which learners produce elaborate language. The analysis of accuracy for the present study focused on the grammatical errors including syntactic, morphological and lexical errors in learners' speech. The complexity of production was measured in terms of T-unit length. The T-unit was developed by Hunt (1970) as an index of syntactic maturity in writing and has been used as a research tool to measure the syntactic complexity of speech and writing samples in L1 and L2 research (Whyte, 1992, 1993, 1994; Ellis, 2005).

The research questions were:

1. What is the relationship between topic familiarity and the fluency of second-language learners' oral production?

2. What is the relationship between topic familiarity and the syntactical development of second-language learners' oral production?

\section{Method}

Participants in this study were 26 Taiwanese college students-23 females and three males. All of them were English-major seniors with high-intermediate English proficiency. The male-female ratio in this study reflects the English-major student population in Taiwanese universities. They were all native speakers of Mandarin. They learned English 
as their foreign language and were recruited from the English Department based on their availability at the time of the data collection. The task each participant was instructed to do was to have two conversations, both with the same partner. The purpose of the study was not revealed to the participants. Unlike the previously mentioned studies, in which participants were interviewed by a stranger or were asked to have a conversation with different persons on different topics, all 26 students each had two conversations, one on a familiar topic, and the other on an unfamiliar topic, with a conversation partner each participant selected for him/herself (usually the subject's best friend in the group), which resulted in 26 dyads in total. Allowing participants to converse on both topics with one conversation partner of their own selection minimized the interlocutor effect as a confounding variable in the study. This study employed a counterbalanced design. Half of the participants would start with the unfamiliar topic and the other half with the familiar topic.

Concerning the selection of conversation topics, instead of having the researcher assign the discourse topic for participants, an approach employed by several researchers, in this study the participants were asked to select the discourse topics on which they would prefer to talk because it was believed that it is the participant who knows the topic with which he/she is most familiar rather than the researcher. Each pair of participants was instructed to select one topic that they felt they were knowledgeable about, that they felt was important to them and that they were interested in talking about. The two participants were also asked to choose one topic with which they were unfamiliar. Twenty minutes were given for the participants to discuss the two topics with their partner. All the instructions were given in Mandarin. In order to avoid fatigue, there was a 10-minute break in between the two conversations. Each conversation lasted from three to ten minutes. The conversations were audiotaperecorded and then transcribed. The familiar/unfamiliar topics chosen by the participants are listed in Table 1.

As mentioned above, this study examined participants' performance from the perspectives of fluency and syntactic development. The performance of the participants' interlocutors was beyond the scope of the present study. Fluency was measured in terms of the speech rate, the total number of words uttered across topics, the mean number of turns and the mean turn length. The speech rate for each topic was calculated by dividing the total time at talk by the total number of words (i.e., number of words per minute). For the purposes of this study, filler pauses, such as "uh" and "um" were excluded from the word count. In addition to the 
speech rate, global measures such as the amount of talk and the mean length of turns were used to gauge learner fluency. Talk on each topic was timed in its entirety. The participant's turn was timed from the end of the preceding interlocutor's turn to the beginning of the following one. Mean turn length was calculated by dividing the total time at talk of the participant by the number of turns the participant took.

Table 1. The familiar/unfamiliar topics chosen by the participants

\begin{tabular}{|c|c|c|c|}
\hline Familiar topics & \multicolumn{2}{|c|}{$\begin{array}{c}\text { Number of partici- } \\
\text { pants who selected } \\
\text { the topic }\end{array}$} & \multirow{2}{*}{$\begin{array}{l}\text { Unfamiliar topics } \\
\text { computer programs }\end{array}$} \\
\hline pets & 2 & 2 & \\
\hline favorite foods & 3 & 1 & selection of notebooks \\
\hline movies & 4 & 1 & function of $\mathrm{Mp3}$ \\
\hline TV programs & 2 & 1 & mobile phones \\
\hline childhood & 3 & 4 & $\begin{array}{l}\text { sports: baseball, basket- } \\
\text { ball, swimming, tennis }\end{array}$ \\
\hline jet lag & 1 & 1 & Egyptian mummies \\
\hline Christmas party & 3 & 2 & online games \\
\hline $\begin{array}{l}\text { the experience of being } \\
\text { an exchange student in } \\
\text { the United States }\end{array}$ & 1 & 1 & $\begin{array}{l}\text { the experience of teach- } \\
\text { ing children English }\end{array}$ \\
\hline fashion & 2 & 2 & tea, coffee \\
\hline travel & 3 & 1 & Mexican food \\
\hline shopping & 2 & 2 & $\begin{array}{c}\text { music: classical, New } \\
\text { Age music }\end{array}$ \\
\hline & & 2 & religion \\
\hline & & 2 & car \\
\hline & & 2 & paintings \\
\hline & & 1 & dinosaurs \\
\hline & & 1 & cooking \\
\hline
\end{tabular}

Each participant's syntactic development was measured in terms of the grammatical complexity and grammatical accuracy of utterance. The analysis of syntactic complexity began with division of the transcription data into T-units and was measured by the number of words per T-unit. 
This analysis used Hunt's (1970) definition of T-units as an independent clause plus all associated dependent clauses. The output of Brady, one of the participants in this study, serves to illustrate the process by which participants' speech was divided into T-units. Her utterances "/ I have been to the United States for one year. / / And I went there because I was studied in the exchange student program./" were coded as two separate T-units, indicated by slashes. The mean length of T-units was calculated by dividing the total number of words of each participant on each topic by the total number of T-units on each topic. This is an index of subordination which provides a measure of the complexity of a stretch of discourse.

With regard to the analysis of grammatical accuracy, the focus was on the grammatical errors including syntactic, morphological and lexical errors in learners' speech; hence, the phonological deviations were ignored except for the final stop sounds and the grammatical markers indicating person and number. The grammatical errors in the participants' oral production were checked by a native speaker of English. An example of an utterance with errors is the following:

\section{Example 1.}

Sometimes I will go to play marble.

To measure grammatical accuracy, the error rate on each discourse topic was calculated by dividing the total number of errors made in each topic by the total number of T-units.

\section{Results}

Results are presented below in terms of fluency and grammatical development.

\section{Fluency}

Table 2 shows the overall mean number of words uttered per minute: 60.19 words for the familiar topics and 41.44 words for the unfamiliar topics. This difference was found to be significant using the matched t-test, $t=$ 7.303, $\mathrm{p}<0.01$. Overall, the participants spoke faster and were more fluent on topics they were familiar with. Table 3 illustrates the mean number of words uttered across topics within three minutes of a conversation. It was found that participants uttered significantly more words within the time 
span of conversation on a familiar topic than they did on an unfamiliar topic. Table 4 presents the mean number of turns taken within three minutes of a conversation across topics. As can be seen in Table 4, the total number of turns taken within three minutes of a conversation varied, ranging from 25 to 5 turns for the familiar topics, and from 21 to 3 turns for the unfamiliar topics. The mean number of turns taken was 14.15 for the familiar topics and 13.31 for the unfamiliar topics. The mean length of turn is presented in Table 5, where we see that the length of the turn on familiar topics (16.90 words per turn) was greater than on unfamiliar topics (9.32 words per turn). The difference was found to be statistically significant using the matched t-test, $t=5.907, \mathrm{p}<.01$.

It is not surprising that the mean number of turns taken for the familiar topics and the unfamiliar topics was similar (14.15 vs. 13.13) because the data were dyadic conversations. The results indicate that participants speak more fluently in terms of the speech rate, talk more and hold the floor longer when talking on a familiar topic. An illustrative example: J talked on his familiar topic- "how jet lag affects the performance of professional baseball teams." As seen in this example, J, "the topic expert" did most of the talking. Aside from producing significantly more words, J also frequently checked the listener's comprehension by asking "you know?" and "do you understand?" and the listener's knowledge about the topic by asking "you know what is the reason?" His partner simply listened to him talking, then asked and responded to questions.

\section{Example 2.}

J: Do you know jet lag will affect the performance of professional baseball teams?

C: Jet lag have affected the performance?

$\mathrm{J}$ : The performance of professional baseball teams, you know?

C: No, I don't know.

J: OK, I'll tell you. In America, there are more than 19 teams and you know, some of them are in Eastern or Pacific time zones. Sometimes a team will travel from one coast and the other.

C: When they arrive in the place where they will have a game, and don't they have enough time to take a rest?

J: OK, well, you know, in America, there are many many 
baseball teams. So, their games will play very frequently, you know. So, they have, they haven't enough time to get enough rest. So, when they arrive to another team's home, they'll got to play. So, I'll give you a study. This study shows that changing time zones may hurt the performance of West Coast baseball teams traveling east for a game, but you know not East Coast teams traveling west. The reason, you know what is the reason?

C: No, I don't know.

$\mathrm{J}$ : OK, The researchers think is that people traveling east suffer more from the symptoms of jet lag. OK. I will give you an example.

C: OK.

J: In 1993, the San Francisco Giants and the Atlanta Braves try to their best to be the winner. The winner of the best-of-seven series goes on to play in the World Series to determine the best team in baseball. Do you understand?

C: Yeah, go on.

Table 2. Number of words uttered per minute between topics (The unit is words)

\begin{tabular}{lcccc}
\hline Topic type & High & Low & $M$ & SD \\
\hline Familiar & 93 & 29 & 60.19 & 17.96 \\
Unfamiliar & 58 & 8 & 41.44 & 20.45 \\
\hline
\end{tabular}

$t=7.303, \mathrm{p}<0.01$

Table 3. Total number of words uttered across topics within a 3-minute conversation

(The unit is words)

\begin{tabular}{lcccc}
\hline Topic type & High & Low & $M$ & $S D$ \\
\hline Familiar & 281 & 89 & 180.58 & 53.87 \\
Unfamiliar & 174 & 25 & 124.31 & 61.35 \\
\hline
\end{tabular}

$t=7.303, \mathrm{p}<.01$ 
Table 4. Mean number of turns taken within a three-minute interaction across topics

\begin{tabular}{lcccc}
\hline Topic type & High & Low & $M$ & $S D$ \\
\hline Familiar & 25 & 5 & 14.15 & 6.04 \\
Unfamiliar & 21 & 3 & 13.31 & 6.08 \\
\hline
\end{tabular}

Table 5. Mean length of turn across topics, in words

\begin{tabular}{llcrr}
\hline Topic type & High & Low & $M$ & \multicolumn{1}{c}{ SD } \\
\hline Familiar & 29.2 & 8.16 & 16.90 & 10.46 \\
Unfamiliar & 13.75 & 3.35 & 9.32 & 5.43 \\
\hline
\end{tabular}

$t=5.907, \mathrm{p}<.01$

\section{Grammatical Development}

The measurement of grammatical development involves two levels of analysis: syntactic complexity and syntactic accuracy. The effect of topic knowledge on learners' syntactic complexity is measured in terms of the mean length of T-units. The matched t-test was computed to examine the differences. The means in Table 6 show that the mean length of Tunits produced by the subjects was 6.99 words for familiar topics and 5.55 words for unfamiliar topics. The matched t-test detected a significant difference between the two types of topics, $t=5.469, \mathrm{p}<0.01$. This indicates that learners produced more complex structures on the familiar topics than on the unfamiliar topics.

Table 6. Mean length of T-units between topics, in words

\begin{tabular}{lcccc}
\hline Topic type & High & Low & $M$ & $S D$ \\
\hline Familiar & 9.95 & 5.32 & 6.99 & 1.28 \\
Unfamiliar & 7.58 & 2.86 & 5.55 & 1.44 \\
\hline
\end{tabular}

$t=5.469, \mathrm{p}<0.01$

Table 7 reveals that the mean number of errors produced by the subjects was 0.63 per T-unit on the familiar topics and 0.44 on the unfamiliar topics. The matched t-test did detect a significant difference in the error rate between the two types of topics, $t=4.22$, $p<0.01$. In other words, participants produced less accurate speech on the topics they were familiar 
with. Eager to share what they knew with their interlocutor and yet with limited ability to manage both content and linguistic form, the participants seemed to give priority to the content of the message when talking on the familiar topics. The following example serves as an illustration. Participant B, talking on her familiar topic, focused on the content so intently that she made lots of grammatical mistakes and, attempting to self-correct, used the wrong linguistic form.

Table 7. Mean number of errors per T-unit between topics

\begin{tabular}{lllrr}
\hline Topic type & High & Low & $M$ & $S D$ \\
\hline Familiar & 1.04 & 0.28 & 0.63 & 0.21 \\
Unfamiliar & 1 & 0.16 & 0.44 & 0.22 \\
\hline
\end{tabular}

$t=4.22, \mathrm{p}<0.01$

\section{Example 3.}

B: I remember my childhood. Sometimes I will go to play marble. Do you know marble?

A: No. What's that?

B: Marble, before you play this game, you should dig a small hole on the ground. So, then you play it. But, finally, which one is winner, then he or she can get more marbles from others. I remember, near my home, there have a small mountain. On holiday or summer or winter vacation, we will go there because there have a river on it. And sometimes we will draw fish and take them go home with us.

A: So, you play marble in the river?

B: No, usually play it on the ground. We don't play it in the water on the water.

\section{Discussion and Conclusion}

While intuition and common sense suggest that an interlocutor's topic knowledge affects his/her oral performance, the precise effects of discourse topic on the oral production of second language learners have not been established. 
The results show that discourse topics do affect second-language learners' conversational participation. It was found that participants produced significantly more words and held the floor longer when talking about a topic with which they were familiar. Similarly, the results of the fluency analysis manifested cross-topic variation in NNS-NNS conversational data. The participants, overall, were more fluent, as measured by counting the total number of words uttered per minute, on topics they were familiar with. As far as grammatical complexity is concerned, the degree of syntactic complexity of the subjects' oral production changed according to their familiarity with the discourse topics. The overall mean length of T-unit produced by the participants was significantly longer for the familiar topic than it was for the unfamiliar topic. With regard to accuracy, the results showed that the error rate produced by subjects for the familiar topic was higher than that for the unfamiliar topic. To sum up, analysis of the data reveals that participants were more fluent, produced longer T-units and had more syntactical errors when conversing on a topic with which they were familiar. The finding that participants produced more errors on a familiar topic could be due to their more active participation. Familiarity with the discourse topic enabled them to talk more and be more willing to take risks-using whatever linguistic forms they needed to express themselves.

Higher error rates on familiar-topic talk also indicate that secondlanguage learners' content knowledge and L2 linguistic knowledge develop separately. The discourse domain hypothesis holds that discourse domains influence the syntactic units of IL learning. While there is no doubt that discourse topics and linguistic forms correlate to a certain extent, expertise in one topic area does not guarantee the mastery of L2 linguistic knowledge needed to express learners' content knowledge. For example, several participants in this study chose "childhood" as their familiar topic. This discourse topic entails the use of past tense. While all the participants in this study, as English-major seniors, knew the past tense, their performance did not seem to correspond to their competence in the use of past tense for a familiar-topic talk. Other errors that the participants frequently made include subject-verb agreement, singular/ plural, word choices and sentence structure.

As already noted, most researchers (Selinker and Douglas, 1985, 1986, 1989; Whyte, 1992; Cornu \& Delahaye, 1987; Zuengler, 1989) investigating topic-related interlanguage variation contrasted subjects' performance on the academic major topic with life domain topics and found that subjects performed better on the academic major topic. The fact that none of the 
participants in the present study chose their academic major topic as their familiar topic when they had a choice to select a familiar topic to speak on could be interpreted in two ways. First, this simply manifests a personal choice and is unrelated to the topic familiarity issue. In other words, they might be familiar with the academic major topic, yet simply preferred not to talk about it when participating in a study. Another interpretation of the unpopularity of the academic major topic as participants' choice of familiar topic may, however, indicate that the academic major topic is not on the list of their familiar topics, which suggests that caution needs to be taken lest a researcher assume that the academic major topic is the familiar topic for all the subjects. This also implies that researchers need to take the time to discover what topics subjects are, or are not, familiar with before assigning a given topic to them.

The finding that the extent to which second language learners are familiar with the discourse topic has a dramatic impact on the fluency of their oral production strongly implies that the topic variable needs to be taken into account when teachers assess L2 students' oral proficiency. A single test does not reveal the complete picture of a student's oral proficiency because the topic may help or hinder their performance. In order to make accurate judgments about students' oral proficiency, teachers need to have students speak on more than one topic.

In classroom instruction, it is difficult for a teacher to choose topics which all students are interested in, familiar with, or willing to explore. In order to improve second-language learners' real-time oral production skills, teachers need to expose students to a mix of topics, some familiar and some not. Familiar topics increase learners' motivation and interest to talk. Learners can build confidence while they talk on the familiar topics. This can also apply to writing since both speaking and writing skills are closely related. The findings of the present study showed that students had a higher error rate on familiar topics. Teachers, therefore, need to help students improve the accuracy of their oral production when they talk on familiar topics. Teachers can record students' oral production and have them listen again and transcribe what they have talked about and look for the errors in their speech. In so doing, teachers raise learners' consciousness regarding their frequent grammatical errors.

Teachers should not avoid seemingly less interesting or less engaging topics since the teaching and practice of the less familiar topics builds up both learners' content knowledge and language ability. It sets high demands on the teacher to strike a balance between the topics chosen and the activities built around the topic. If the teacher assumes that the 
students are not familiar with a certain topic, he or she may assist them to build up both their content knowledge and linguistic knowledge by providing "advance organizers" (Ausubel, Novak \& Hanesian, 1978) such as related reading assignments, vocabulary lists and pre-introduction to the topic. Since L2 learners may be interested in, or familiar with, different topics, asking each student to give a presentation in class on a topic that $\mathrm{s} /$ he is interested in or familiar with is another way to expand learners' verbal repertoire.

The primary limitation of this study was the unbalanced male-female ratio. Further research involving a balanced male-female ratio is needed in order to investigate whether the findings of the present study span the effects of gender. Moreover, the subjects of this study only consisted of Taiwanese adult students. Generalizability to other demographics needs to be demonstrated as part of the future research agenda in this area.

\section{References}

Ausubel, D., Novak, J., \& Hanesian, H.(1978). Educational psychology: A cognitive view. New York: Holt, Rinehart and Winston, Inc.

Chang, Y.F. (2002). Discourse topics and interlanguage variations. ERIC Document Reproduction Service No. ED 465275.

Cornu, A.M., \& Delahaye, M. (1987). Variability in interlanguage reconsidered: LSP vs. non-LSP IL talk. English for Specific Purposes, 6(2), 145-151.

Douglas, D., \& Selinker, L. (1992). Analyzing oral proficiency test performance in general and specific purpose contexts. System, 20(3), 317-328.

Douglas, D., \& Selinker, L. (1993). Performance on a general versus a fieldspecific test of speaking proficiency by international teaching assistants. In D. Douglas, \& C. Chapelle (Eds), A new decade of language testing research (pp. 235-256). Alexandria, VA: TESOL.

Douglas, D., \& Selinker, L. (1994). Research methodology in context-based second-language research. In E. Tarone, S. Gass, \& A. Cohen (Eds.), Research methodology in second-language acquisition (pp. 119-131). Hillsdale, NJ: Lawrence Erlbaum Publishers.

Eisenstein, M., and Starbuck. R. (1989). The effect of emotional investment on L2 production. In S. Gass, C. Madden, D. Preston, \& L. Selinker (Eds.), Variation in second language acquisition: Psycholinguistic issues (pp.125-137). Clevedon, UK: Multilingual Matters.

Ellis, R. (2003). Task-based language learning and teaching. Oxford: Oxford University Press.

Ellis, R. (2005). Analyzing learner language. Oxford: Oxford University Press. 
Hunt, K.W. (1970). Recent measures in syntactic development. In M. Lester (Ed.), Readings in applied transformational grammar. New York: Holt, Rinehart, and Winston.

Lennon, P. (1990). Investigating fluency in EFL: A quantitative approach. Language Learning, 40, 387-417.

Riggenbach, H. (1991). Toward an understanding of fluency: A microanalysis of nonnative speaker conversations. Discourse Processes, 14, 423-441.

Schmidt, R. (1992). Psychological mechanisms underlying second language fluency. Studies in Second Language Acquisition, 14, 357-385.

Selinker, L., \& Douglas, D. (1985). Wrestling with context in interlanguage theory. Applied Linguistics, 6(2), 190-204.

Selinker, L., \& Douglas, D. (1986). The problem of comparing episodes in discourse domains in interlanguage studies. ERIC Document Reproduction Service No. ED308710.

Selinker, L., \& Douglas, D. (1987). The problem of comparing episodes in discourse domains in interlanguage studies. In F. Marshall (Ed.), Proceedings of the Third Eastern States Conference on Linguistics (pp. 467-478). Columbus, OH: Ohio State University Press.

Selinker, L., \& Douglas, D. (1989). Research methodology in contextually-based second language research. Second Language Research, 5, 93-126.

Skehan, P. (1996a). A framework for the implementation of task-based instruction. Applied Linguistics, 7, 38-62.

Skehan, P. (1996b). Second language acquisition research and task-based instruction. In J. Willis, \& D. Willis (Eds.), The challenge and change in language testing. (p. 12) Oxford: Heinemann.

Smith, J. (1989). Topic and variation in ITA oral proficiency: SPEAK and FieldSpecific tests. English for Specific Purposes, 8, 155-167.

Smith, J. (1992). Topic and variation in the oral proficiency of international teaching assistants. Unpublished doctoral dissertation, University of Minnesota, Minneapolis.

Tarone, E. (1988). Variation in interlanguage. London: Edward Arnold.

Whyte, S. (1992). Discourse domains revisited: Expertise and investment in conversation. In L. Bouton, \& Y. Kachru (Eds.), Pragmatics and language learning (Vol. 3, pp. 81-103). Urbana, IL: DEIL, University of Illinois.

Whyte, S. (1993). The discourse domain hypothesis: Topic-related variation in interlanguage production. Ph.D qualifying paper, Indiana University, Bloomington.

Whyte, S. (1994a). Acquisition in context: The effect of topic knowledge on second language. In L. Bouton, \& Y. Kachru (Eds.), Pragmatics and language learning (Vol.5, pp. 289-315). Urbana, IL: DEIL, University of Illinois. 
Whyte, S. (1994b). The role of specialized knowledge in interlanguage variation: The discourse domain hypothesis. Unpublished doctoral dissertation, Indiana University, Bloomington.

Whyte, S. (1995). Specialist knowledge and interlangauge development: A discourse domain approach to text construction. Studies in Second Language Acquisition, 17(2), 153-183.

Woken, M.D., \& Swales, J. (1989). Expertise and authority in native-non-native conversations: The need for a variable account. In S. Gass, C. Madden, D. Preston, \& L. Selinker (Eds.), Variation in second language acquisition: Discourse and pragmatics (pp.211-227). Clevedon, UK: Multilingual Matters.

Young, D. (1991). Activating student background knowledge in a take-charge approach to foreign language reading. Hispania, 74(4), 1124-29.

Zuengler, J. (1989) Performance variation in NS-NNS interactions: Ethnolinguistic difference or discourse domain? In S. Gass, C. Madden, D. Preston, \& L. Selinker (Eds.).Variation in second language acquisition: Discourse and pragmatics (pp.218-235). Clevedon, UK: Multilingual Matters.

Zuengler, J. (1993a). Explaining NNS interactional behavior: The effect of conversational topic. In G. Kasper, \& S. Blum-Kulka (Eds.), Interlanguage pragmatics (pp.184-195). Oxford: Oxford University Press.

Zuengler, J. (1993b). Encouraging learners' conversational participation: The effect of content knowledge. Language Learning, 43(3), 403-432.

Zuengler, J., \& Bent, B. (1991). Relative knowledge of content domain: An influence on native-non-native conversations. Applied Linguistics, 12(4), 397-415. 
